\title{
Adjective-Noun Order: An Error Analysis of Colombian Learners of English ${ }^{1}$
}

Orden Adjetivo-Sustantivo: Un Análisis de Error de Los Estudiantes Colombianos de Inglés

\section{Andrew John Connolly ${ }^{2 *}$}

Universidad EAN, Colombia

\footnotetext{
${ }^{1}$ Received: April $3^{\text {rd }}$ 2019/Accepted: April 23 ${ }^{\text {rd }} 2020$

2 aconnolly1@gmail.com
} 


\section{Abstract}

Adjective- noun order errors are a common occurrence throughout all levels of English language students. Based on professional experiences, existing literature and revisiting what some may consider archaic methodologies, this reflective article aims to analyse adjective-noun order errors among Colombian learners of English, understand why it presents such a challenge in the Colombian context and provide one possible teaching method to help reduce the number of adjective-noun order errors produced. To achieve such aims this article compares the rules for adjective-noun order in English and Spanish, describes the implications of the differences in adjective-noun order between the two languages for the Colombian learner and proposes translation as a teaching method to help Colombian learners of English reduce the frequency of these errors. Further investigation is needed to provide teachers with more insight into this problem; perhaps, focussing specifically on one of the two skills in which the error is produced, either writing or speaking.

Key Words: Adjective-noun order; Colombian learners of English; Translation method; Error analysis

\section{Resumen}

Este artículo explora el desafío del orden adjetivo-sustantivo entre los estudiantes de inglés colombianos. Los errores en el orden de los sustantivos y los adjetivos son un hecho común que se puede apreciar en todos los niveles entre los estudiantes de inglés en Colombia. Basado en las experiencias profesionales, la literatura existente y revisando lo que algunos pueden llamar metodologías arcaicas, este artículo reflexivo tiene como objetivo analizar los errores de orden de los adjetivos y sustantivos entre los colombianos que estudian inglés, comprender por qué genera un desafío en el contexto colombiano y así mismo, brindar un método de enseñanza posible para ayudar a reducir el número de errores de orden de adjetivo-sustantivo producidos. Para lograr tales objetivos, este artículo compara las reglas del orden adjetivo-sustantivo en inglés y español, describe las implicaciones de las diferencias en el orden adjetivo-sustantivo entre los dos idiomas y propone la traducción como un método de enseñanza para reducir la frecuencia de estos errores y así ayudar a los aprendices de inglés colombianos. Se necesita más investigación para proporcionar a los maestros más información sobre este problema; tal vez, centrándose específicamente en una de las dos habilidades en las que se produce el error, ya sea escribiendo o hablando.

Palabras claves: Orden adjetivo-sustantivo; estudiantes colombianos de inglés; método de traducción; análisis de errores.

\section{Resumo}


Os erros de ordem adjetivos-substantivos são uma ocorrência comum nos estudantes de todos os níveis de aprendizagem de inglês. Baseado em experiência profissional, a existente literatura e revisão do que alguns podem considerar metodologias arcaicas, este artigo reflexivo tem como objetivo analisar os erros de ordem adjetivos-substantivos entre estudantes colombianos de inglês, compreender por que se apresenta tal desafio no contexto colombiano e proporcionar um possível método para ajudar a reduzir o número de erros produzidos. Para alcançar tais objetivos, este artigo compara as regras para estabelecer a ordem adjetivo-substantivo em inglês e espanhol, descreve as implicações das diferenças na ordem adjetivo-substantivo entre os dois idiomas para o aprendiz colombiano e propõe a tradução como um método para ajudar os estudantes de inglês a reduzir a frequência destes erros.

Palavras chave: ordem adjetivo-substantivos; estudantes colombianos de inglês; método de tradução; erro de análise 


\section{Introduction}

magine a scenario where a basic rule was explained to you which you must follow; however, no matter how well you understood that rule you still failed to obey it. For example, you are completely aware that in order to start a parked car you must take off the hand brake before you attempt to move it but more often than not when you attempt to perform such a manoeuvre you try to move the car with the hand brake on and the car cuts out, leaving you frustrated. I witness a similar level of frustration when one of my language students realises that they have produced a basic error. An error which is well below their current level and one which they are quite aware of the rules required to avoid. One such error is adjective-noun order. To an English language teacher, the knowledge needed to understand how adjectives and nouns are ordered would appear to be minimal, nonetheless, the prevalence of adjective-noun order errors produced in both spoken and written output in the Colombian classroom is surprising.

The apparent simplicity of adjective-noun order in English is what makes this error an intriguing one to investigate. As interesting as the error itself, is the lack of studies relating to this error in a Colombian context. According to Sanchez-Ruiz and Lopez (2014) adjective-noun order errors are some of the most common among Spanish speaking learners of English so it would appear necessary to look further into this problem to discover possible reasons why Colombian learners of English struggle with this grammar point and to provide some methods for teachers to use to attempt to reduce these errors. That is what this article aims to achieve. The paper begins with a description of the specific challenges facing Colombian leaners in relation to adjective-noun order, then an analysis of adjective-noun order in English, followed by a similar analysis of adjective-noun order in Spanish. Finally, the paper provides a discussion and one possible method to help Colombian learners and their teachers with these challenges.

\section{Challenges Faced by Colombian Learners with Adjective-Noun Order}

\section{The Process of Error Analysis}

Corder (1975) states that when undertaking an error analysis, it is important to be able to distinguish between mistakes and errors. Corder's (1975) observation appears a valid one since if we are undertaking an error analysis then mistakes must not be included. For that reason, a clear line needs to be drawn between the two (Corder 1967, cited in Ellis. 1994). However, such a clear line does not exist as the differences between errors and mistakes can be blurry and subjective (Ellis, 1994; Hinkel, 2018). 
Corder (1967, cited in Ellis,1994) was the first to attempt to define the differences between an error and a mistake. Using Chomsky's distinction (cited in Ellis, 1994) Corder (1967) associated errors with failures in competence and mistakes with failures in performance.

Later, Corder (1971) developed what he coined the auto-correction method. Corder (1971) claims that auto-correction is the key to deciding whether a mistake or error has occurred. He states that a mistake occurs if a learner is made aware of a faulty sentence or utterance and is then able to correct it by themselves since it is related to performance rather than competence. If; however, the learner is unable to correct the faulty sentence or utterance, it is then defined as an error. While this method of differentiation may seem straightforward, James (1998) identifies one possible issue with Corder's (1971) auto-correction method. James (1998) uses the example of a student submitting an essay in an exam. Before submitting the essay, the student would have re-read the essay numerous times to check and correct errors. Then, when the student is convinced that the essay is error free; the essay is submitted. However, after the teacher revises the essay and finds some ungrammatical forms and then informs the student of the location of the ungrammatical forms, a problem arises with defining the ungrammatical forms as errors or mistakes. The problem with the auto-correction method lies in the fact that the student can correct his or her work but only after being made aware of the need to make corrections. In other words, is it still just a mistake if a learner does not identify the problem by themselves but can auto correct after they are made aware of the deviant form by a second party?

Another possible hurdle in using the auto-correction method is the need for the student to be present while the correction process takes place. Ellis (1985, cited in Tim, 2000) claims that in cases where the student is not available, if a deviant form keeps on recurring then it is probably an error. The frequency of the same deviant can help identify that an error has occurred since if an identical deviant is reoccurring it demonstrates a gap in competence rather than a performance slip. James (1998) also suggests that frequency is a valid index of the gravity of error with a higher frequency equating to a higher gravity of error.

In the case of adjective-noun order, the distinction is difficult, as learners may be aware of the rule; however, fail to consistently produce correctly ordered utterances. The frequency with which the inaccuracies of adjective-noun order occur (SanchezRuiz \& Lopez, 2014) provides a strong case for the failure to be classified as an error and not a mistake. With that in mind, adjective-noun order inaccuracies are defined as errors in this article.

To summarise, a mistake is something that occurs in performance and it can be selfcorrected by the learner. An error is something that occurs due to a lack of knowledge or competence and is usually not able to be self-corrected by a learner without further learning. In the absence of a learner to self-correct, the frequency of an incorrect form 
can confirm if a genuine error has occurred. The analysis in the following sections shows that in Spanish, adjective order has greater flexibility than in English. Hence, when a Colombian learner is faced with the decision of ordering multiple adjectives or deciding to put the adjective before or after the noun, it presents a serious challenge. For example, a learner says, "big car red", instead of, "big red car".

When a language learner uses their L1 to produce the target language it can either help the learner produce something correct, this is known as positive transfer or facilitation, or it can hinder the learner and cause them to produce something incorrect, this is known as negative transfer or interference (Gass \& Selinker, 2008). Since this article is focussed on errors, it mainly considers negative transfer; although, positive transfer is briefly mentioned in the discussion section of this article.

Negative transfer happens when learners transfer items and structures which are not the same in L1 and L2 (Hussein \& Mohammad, 2010). It could be said that negative transfer is the cause of adjective-noun order errors among Colombian learners of English. Proof of such claim can be seen when the incorrect utterance is translated back into Spanish. For example, "big car red" translated directly, with the same word order into Spanish gives "gran carro rojo", which is grammatically correct in Spanish.

We have defined adjective-noun order inaccuracies as errors; however, it may seem to some as a less serious error. This may be true since some errors are more severe than others. To scale the severity of an error, Burt (1975) classified errors as either being local or global. Local errors refer to errors which make the sentence sound strange but do not affect intelligibility in a major way while global errors are errors which affect intelligibility, leading to the message either being misinterpreted or not understood at all. Errors relating to adjective-noun order could be categorised as more local errors, as the meaning of "big car red" may be understood through context, especially for those familiar with Spanish. However, global errors could also occur if the learner was speaking with someone unfamiliar with the Spanish language. Teachers with some understanding of the learner's L1 may become desensitised to these errors and have a system of comprehension already in place to make understanding of such errors easier (Hanzeli, cited in Hendrickson, 1978). Camps, Villalobos and Shea (2012) also found that teachers who live and teach in a non-English speaking become accustomed to the errors which are made most frequently. So, in some cases it can affect intelligibility and in cases where it does not seriously impact intelligibility, the error can cause difficulty to the listener or embarrassment to the speaker (Camps et al., 2012). In either case it is not satisfactory to let the error persist.

Gass and Selinker (2008) define two error types different from Bert's (1975) global and local errors. Gass and Selinker (2008) explain that an error can be classified as either interlingual if the error can be attributed to the learner's L1 or intralingual if the error can be attributed to the target language and is independent of the learner's L1. These error types differ from Bert's (1975) since they deal with error source rather 
than the severity of the error. So, adjective noun order can also be classified as an interlingual error since it would appear to come from inference from the learner's L1.

However,accordingto(Ellis\&Barkhuizen,2005)L1 interferenceisnottheonlysourceof difficultyinL2acquisition.Apartfrom thedifferencesinrulesbetweenSpanishandEnglish, the learning environment of Colombian learners of English also provides challenges to the learner regarding adjective-noun order. The paper now discusses these challenges.

\section{Other Factors}

The English as a Foreign Language (EFL) learning environment, within Colombia, limits both the amount of exposure to the English language and the number of opportunities for a student to practice English. Along with the fact that learners live in a non-English speaking environment, Colombian language institutes are also following the global trend of implementing Communicative Language Teaching (CLT) to second language learning. While this approach has seen great success in English as a second language (ESL) environments, it has had mixed results in EFL environments (Li, 1998). There are many issues with CLT in the EFL environment (Cardenas, 2006), but the one which directly affects adjective-noun order is the focus on fluency over accuracy. CLT allows for greater tolerance of errors in return for creating an atmosphere which promotes spontaneous use of the target language (Lightbown \& Spada, 1990). As mentioned earlier, English teachers in a non-English speaking country frequently become desensitised to commonly repeated errors (Camps et al., 2012). As a result of this desensitisation, teachers only focus on problems which are subjectively believed to be more serious. This can lead to students carrying basic grammar problems from level to level without being corrected. One such problem, in the author's opinion, is adjective-noun order errors. Reaching communicative competence involves a balance between fluency and accuracy (Phettongkam, 2013) and it is important that teachers in EFL environments begin to pay more attention to this fact.

A second factor is the learners' experiences of learning a foreign language. Learner experience is very important in the Colombian university context because some of the students at university have had very different primary and secondary school experiences with English. There is a widening gap between private and public education in Colombia and this difference has a huge influence on the proficiency levels that students achieve and bring to the tertiary level of education (Velez-Rendon, 2003). In Colombia, many private schools are bilingual, and the teachers there consider themselves to have an adequate level of English, in contrast, public-school English teachers admit to having a very low proficiency and in some cases none (Velez-Rendon 2003). The factor of low-level English teachers affects many aspects of a learner's experience and not just adjective-noun order. However, it is an important factor to consider in the Colombian context since it is a reality for many university level students. So, in the cases where students had English teachers who were incapable of speaking English let alone 
teaching it, the understanding of why some basic aspects of English are erroneously produced becomes easier to comprehend. After detailing the challenges faced by Colombian learners, the paper now provides an analysis of adjective order in English.

\section{Adjective Order in English}

Adjectives can have three positions in the English language: prenominal position, predicative position, and postpositive position. The paper now discusses these three positions in greater detail and describes those factors which affect adjective-noun order.

\section{Prenominal Adjectives}

The following section comprises an insight into both single and multiple prenominal adjectives.

\section{Single prenominal adjectives.}

Single prenominal adjectives are the most straightforward to order, usually taking the second to last position within the noun phrase (Parrott, 2010), for example, 'a very old car'. When dealing with one prenominal adjective the ordering is clear, however, the task of ordering multiple prenominal adjectives is more complex. The following section provides a description of this task.

\section{Multiple prenominal adjectives.}

When faced with more than one prenominal adjective there is a decision to be made as to which adjective should be closer to the head noun. Wulff (2003) proposes that there are four factors which can affect the order of multiple prenominal adjectives including phonological, syntactic, semantic, and pragmatic. However, syntax and semantics are the two areas which influence adjective order the most (McMahon, 2008) and for that reason, those are the factors which the paper focuses on.

\section{Syntactic and semantic factors.}

The relationship between adjective order and semantics is one which raises many challenging questions (McNally \& Kennedy, 2008). The reason is that, in English, adjectives have a greater range of flexibility in relation to order when compared to 
other syntactic categories (McNally \& Kennedy, 2008), for example, sentence structure. For this reason, adjective ordering is characterised by semantic properties (Svenonius, 2007). The examples in (1) and (2) demonstrate that while both sentences have the adjectives before the noun, a native English speaker's intuition would say that (2) is incorrect.

(1) a big red car

(2) * a red big car

Dixon (1977) makes the argument that the adjective with a colour property should be placed closer to the head noun than the adjective with a size property. Examples (1) and (2) show that there is a preferred adjective order in English. Classification of adjectives is something which Dixon (1977) tried to explain with the creation of semantic classes.

There are seven classes, the first class 'colour' is ordered closest to the head noun with the subsequent classes following in the order (1-7) shown below. The class ordered the furthest away from the noun is 'value'.

Below is a list of Dixon's (1977) semantic classes

7. Value (good, bad6. Dimension (big, long

5. Physical Property (hard, sweet)

4. Speed (quick, slow)

3. Human Propensity (happy, kind)

2. Age (new, young)

1. Colour (red, white)

Using Dixon's (1977) semantic classes in real examples, it is clear to see that the classification of adjectives has a meaningful application. Both examples (3) and (4) adhere to Dixon's classification and are syntactically and semantically correct.

(3) a big new promotio

(4) a kind young man

While in many cases Dixon's (1977) semantic classes are clear and functional, the issue of classification shines a light on some of the inadequacies of Dixon's seven classes. Wulff (2003) highlights these inadequacies with the question of where to classify adjectives describing date and time (pre-war, annual), position (left/right), and adjectives which mean 'pertaining to' or 'relating to' (mathematical, financial etc.). Quirk, Greenbaum, Leech and Startvik (1985) propose that the adjective which is 
most (relatively) inherent to the head noun is placed closest to the head and is followed by adjectives relating to opinion. Examining (1) in more detail it is evident how this works, as the car is inherently red, however, the modifier 'large' is a matter of opinion, as the car needs to be compared to another smaller car in order to be perceived as large. Based on this subject objectivity theory, Hetzron (1978) developed a thirteen semantic class scale, however, like Dixon's (1977), there were still adjectives that couldn't be clearly classified.

The syntactic freedom of prenominal adjective order has led to a more semantic approach to preferred adjective order. Matter of opinion and subjectivity make it hard to pin down a definitive all-inclusive order which can be followed. Nonetheless, the semantic classifications that are described above (Dixon, 1977 \& Hetzron, 1978) have been adapted and are being introduced into the classroom. The British Council (n.d.) describe a class system which states that prenominal adjectives are 'usually' ordered as follows: General Opinion > Specific Opinion $>$ Size $>$ Shape $>$ Age $>$ Colour $>$ Nationality $>$ Material. This system accounts for the subjective and inherent properties of prenominal adjectives and orders them appropriately. Having described pre-nominal adjective order in English, the paper now comprises a discussion of post-nominal adjective order in English.

\section{Post-nominal Adjectives}

There are two types of post-nominal adjective positions. The first is known as the predicative position. The predicative position is when the adjective is placed after a noun with a linking verb. A predicate adjective modifies the subject of a noun phrase and is connected to the subject by a linking verb. An example of an adjective in a predicative position can be seen in (5).

(5) The man is old

Swan (2005) provides the following list as the most common linking verbs: be, seem, appear, look, sound, smell, taste, feel, become, get.

The second post-nominal position is postpositive. A postpositive adjective modifies the item which it follows. A postpositive position doesn't require a linking verb. Some adjectives must appear in a postpositive position and in doing so have a different sense (Quirk et al. 1985) to an attributive or predicative position. Quirk et al. (1985) give the example of the adjective 'elect', meaning soon to office.

(6) The president elect

A postpositive position can also describe a more temporary situation. Quirk et al. (1985) provide the following examples: 
(7) The stars visible

(7a) The visible star

In this case, (7) insinuates that the stars are visible at a specific time, while (7a) refers to a group of stars that can always be seen. Having provided an analysis of adjective order in English, a similar analysis of adjective order in Spanish now follows.

\section{Adjective Order in Spanish}

As a learner of Spanish, one often hears the phrase "in case of doubt the learner will be safe in placing the adjective last" (Ramsey, 1956). However, this all-inclusive rule is misleading advice as adjectives in Spanish can occur both before and after the noun being modified, with only 63 per cent of adjectives being found in a postposition (Bull, 1950). In fact, adjective position in Spanish is relatively free, since the position of the adjective can be manipulated for stylistic effect (Kattan-Ibarra \& Pountain, 2003). A description of adjective position in Spanish is now presented, followed by an explanation of how adjective position in Spanish can affect meaning.

\section{Prenominal Position}

In Spanish, adjectives which express inherent characteristics or features which are obvious and known to all, are placed before the noun (8) (Gordon \& Stillman, 1999).

(8) La blanca nieve

the white snow

When expressing a subjective judgement of a speaker the adjective also takes a prenominal position (9) (Gordon \& Stillman, 1999). Common subjective adjectives include nter (good), malo (bad), mejor (better) and peor (worse). Adjectives that express quantity are also normally placed before the noun (10) (Kattan-Ibarra \& Pountain, 2003). Common adjectives of quantity include: mucho (much), poco (little), bastante (a lot) and alguno (some).

(9) vivimos en una pequeña ciudad we live in a small city.

(10) muchísimas preguntas very many questions.

The prenominal position can also be used for non-literal or ironic effect (11) (Kattan-Ibarra \& Pountain, 2003) and exclamations with ¡Qué! (12) (Gordon \& Stillman, 1999).

(11) ni un triste céntimo

not (even) a miserable cent

(12) ¡Qué mala suerte!

What bad luck! 


\section{Post-nominal Adjectives}

Adjectives which express a distinctive or contrastive attribute of a noun are placed post-nominally (Kattan-Ibarra \& Pountain, 2003). Such adjectives can denote nationality (13), place of origin, shape, substance, purpose or colour (14) (KattanIbarra \& Pountain, 2003).

(13) El gobierno irlandés

The Irish government

(14) Una casa azul

A blue house

A post-nominal position is also used to describe a subset of a particular type of noun (Kattan-Ibarra \& Pountain, 2003).

(15) Los libros técnicos

The technical books

In (15) the adjective 'técnicos' is describing some books, from a larger set of books, as technical.

\section{Difference in Meaning}

In Spanish, adjectives can occur in both a pre and post-nominal position, often creating a difference in meaning (Whitley, 1986). Bull (1965) used mathematical organisation to define the difference between the pre and post-nominal position. Bull (1965) states that prenominal position expresses totality (the whole set) while postnominal position expresses partitiveness (subset). In order to explain this, Bull (1965) gives the following examples:

(16) Los blancos caballos de Don Hugo The white horses of Don Hugo

(17) Los caballos blancos de Don Hugo * The horses white of Don Hugo

In the first example, the speaker presumes that all of Don Hugo's horse are white, but in the second the speaker implies that he is talking about those horses of Hugo's which are white (not all of them are white).

\section{Emphasis}

Ramsey (1956) proposed that a postpositive position of an adjective can be used to highlight emphasis. Place and Torres-Rioseco (1943) also support this idea by stating that an adjective which is inherent to the noun is placed in the unstressed position (before the noun), while if the adjective is being used to distinguish itself from others of the same class it is placed in the stressed position (after the noun). Ramsey (1956) provides examples (18) and (19) below. 
(18) vivos colores

(19) colores vivos bright COLORS

colors BRIGHT

In (18) the importance is given to the noun 'colours' and in (19) the importance is given to the adjective 'bright'. Bolinger (1972) developed this idea further drawing parallels between the English verb phrase (VP) and the Spanish noun phrase (NP). Bolinger's (1972) theory was that the last element in the phrase carries the most semantic weight. This theory gave way to what Bolinger (1972) described as "linear modification". Linear modification aims to explain the order in a Spanish NP where there is more than one adjective. Whitley (1986) provides an example (20) of how liner modification functions.

(20) las grandes repúblicas democráticas europeas

${ }^{\star}$ The great democratic republics Europeans

First the determiner 'las', then the speaker wishes to highlight the greatness associated with the republics which are being spoken of. The speaker then sub-classifies the great republics by limiting them to only democratic ones, and finally, the speaker adds the most informative information which is that these great democratic republics belong to Europe. A different organisation of the adjectives would result in a different referential specification of republics (Whitley, 1986).

\section{Specific adjectives}

Apart from highlighting emphasis from the speaker, Ramsey (1956) identified several adjectives which give different meanings in prenominal and post-nominal position respectively. Adjectives mentioned by Ramsey (1956) include; antiguo (old), cierto (true), grande (big), nuevo (new), and pobre (old) amongst others. To demonstrate the differences, Ramsey (1956) provides the following example:

(21) El antiguo nterlang

(21a) El nterlang antiguo the former president

the ancient (very old) president

The above example demonstrates that along with emphasis, adjective-noun order in Spanish can also affect the meaning of an NP.

As is regularly the case in linguistics, there are a number of theories which try to find a definitive answer to a long-standing problem. In the case of this paper, I have summarised the most important theories relating to adjective-noun order in both Spanish and English. Now, the paper provides a discussion and one possible approach to solve the challenges faced by Colombian learners. 


\section{Discussion and Solutions}

The paper thus far has focussed on the challenges faced by Colombian learners and factors which affect adjective-noun order in both English and Spanish. Now, the paper discusses one possible approach which can be used to help Colombian learners understand the differences between English and Spanish adjective-noun order. The approach proposed is use of the learners' L1, in this case Spanish, through translation activities.

Hunter and Smith (2012) describe how older teaching methods tend to be "packed up" and put in the "dustbin of history" as soon as a new approach is revealed. Hunter and Smith (2012) add that the shelving of old methods leads to them being perceived as unnecessary or useless when, in fact, they are connected to or in part led to the discovery of the new approaches. As a teacher who was trained in line with the communicative approach, I have also been guilty of disregarding what appeared to me as outdated methods with no current value. However, my mind has been changed. Translation or use of the students' L1 is one of the methods I overlooked.

As mentioned early, many Colombian language institutes use Communicative Language Teaching in their classrooms. This approach allows for little to no use of the students' first language. According to Kerr (2014) setting first language restrictions are futile since the teacher may be able to control what language is used in the classroom but cannot control how the student thinks. Kerr (2014) explains that even though teachers may explicitly prohibit the use of the students' L1 and translation, students are still constantly translating in their heads. Kerr (2014) then proposes that if these students are already translating on some subconscious level why not take advantage of this by putting it to work for language acquisition.

I now believe that the neglect of translation as a useful tool for language acquisition is a huge oversight as many of the reasons why translation was initially introduced as an approach, for example, the grammar translation method, still stand true to this day. The following section details the reasons why translation is still and always has been a legitimate tool in the language classroom. The reasons below have been selected from Kerr's (2014) work on translation. Not all the reasons Kerr (2014) lists in his work are listed below, only the ones which are relevant to the context of this article.

\section{Own Language as a Reference Point}

Prominent psychologist Vygotsky (1934, cited in Kerr,2014) describes the importance of having some sort of reference point between the world of objects and the new language being learned. The importance of the learners' $\mathrm{L} 1$ is also advocated 
by cognitive linguists and neuroscientists. Many opponents of translation point to the fact that using a learner's L1 in language learning is a bad idea since it can lead to negative transfer or the misunderstanding of false friends (cognates). While it is true that negative transfer and false friends exist, it also true to say that there may be just as many or even more examples of positive transfer and true friends.

It is also worth noting that problems such as negative transfer can be solved through direct comparison of the two languages in question. Word order is one example of negative transfer. An efficient way to create awareness of word order differences is comparing the two languages side by side.

\section{Intercultural Competence}

Identity and language go hand and hand. Learners associate their identity with the language that they grew up speaking. To prohibit the use of a learner's first language in substitute for a foreign language may cause tension. Instead of creating tension, the use of the student's L1 in the classroom can create intercultural competence since the students are driven to understand similarities and differences between the two languages. Mediation is a skill listed in the Common European Framework of Reference for language(North \& Piccardo,2016), it appears contradictory to foster mediation in a classroom while suppressing one language and promoting another.

\section{Practicality}

Along with the cognitive and cultural benefits, use of a learners first language saves time. In some cases, it is the simplest and most time-efficient way to explain certain aspects of language. This is not to say that translation is better in all instances. There are moments where guided discovery, demonstration or explanations take precedence; although, when time is limited translation would appear to be the most efficient option. Variety is key to keeping the class motivated and engaged so adding one more teaching method, in the form of translation, can add to this variety.

To summarise, the use of a learner's L1 in EFL environments receives criticism from supporters of the target language only position as it is believed that use of L1 interferes with the acquisition of the target language (Pan, 2010). However, the benefits of appropriately using a learner's L1 in order to promote the transition from L1 to the target language are beginning to be recognized once more (Shamash, cited in Pan, 2010) (Kerr, 2014). In fact, avoiding the use of the learner's L1 can lead to various problems, one of which is word order error (Macaro, 2005). Using a contrastive analysis of the two languages, a method can be developed to reduce 
errors relating to adjective-noun order. I believe that "reverse translation" activities which permit the use of the learner's L1 can be used to solve this problem. One such activity is described below as a possible example to tackle the noun order error.

Divide the class into pairs and give each pair a text in English. This text should have various examples of the grammar point, in this case, adjective-noun order. Each pair translates the text into their L1. Then, the texts are collected and redistributed throughout the class. The pairs then translate the new text they have received back into English. When all the students have finished, they compare the text they have translated with the original text. This comparison allows the students to discover the contrast in the rules between their L1 and the target language. Activities such as this one can be altered to focus on speaking. For example, a role play which involves one student acting as a tourist and the other as a translator. These types of activities can also help EFL teachers highlight areas of errors which perhaps have slipped under the radar. This sample exercise is limited to monolingual classes such as the ones in Colombia where the majority of students' mother tongue is Spanish. It is also important that the teacher has a solid understanding of the students' L1.

\section{Conclusion}

Adjective noun order is a seemingly small and simple part of English grammar; however, Colombian students at all levels continue to make errors regarding this topic. A clear difference of grammatical rules regarding adjective- noun order between English and Spanish could explain the presence of this error in leaner output. While, the overemphasis on fluency at the expense of accuracy in the communicative teaching method is one possible reason why this type of error has persisted. To solve this problem, a combination of teaching methods is required since the over reliance on one method can lead to some areas of language being developed more than others.

In the case of adjective-noun order errors, an awareness from both the students and teacher of the problem is needed along with the development of activities which deal with the problem. Such activities should take advantage of the student's L1, through translation, to demonstrate the contrast between English and Spanish adjective order and allow them to understand the difference in a more complete way. Along with translation methods other solutions may be possible and need to be further investigated. 


\section{References}

Bolinger, D. (1972). Adjective position again. Hispania, 55 (1), 91-94.

Bull, W. (1950). Spanish adjective position: Present rules and theories. Hispania, 33(4), 297-303.

Bull, W. (1956). Spanish for teachers: Applied linguistics, New York: Ronald Press.

Burt, M.K. (1975) Error analysis in the adult EFL classroom. TESOL Quarterly, 9, 5363.

Camps, D., Villalbos, J., \& Shea, J. (2012). Understanding EFL students' errors: An insight towards their interlanguage. MEXTESOL, 36 (1), 1-12.

Cardenas, M. (2006). Bilingual Colombia: Are we ready for it? What is needed? Conference proceedings of the $19^{\text {th }}$ Annual EA Education Conference. Perth, Australia.

Corder, S.P. (1971). Idiosyncratic dialects and error analysis. International Review of Applied Linguistics, 9(2), 147-160.

Corder, S.P. (1975). Error analysis, nterlanguage and second language acquisition. Language Teaching, 8(4), 201-218.

Dixon, R.M.W. (1977). Where have all the adjectives gone? Studies in Language, 1, 19-80.

Ellis, R. (1994). The study of second language acquisition, Oxford: Oxford University Press.

Ellis, R. (2003). Second language acquisition, Oxford: Oxford University Press.

Ellis, R. \& Barkhuizen, G. (2005). Analysing Learner Language, Oxford: Oxford University Press.

Gass, S.M. \& Selinker, L. (2008) Second Language Acquisition: An Introductory Course, New York: Routledge.

Gordon, R. \& Stillman, D. (1999). The ultimate Spanish review and practice, Chicago: Passport Books.

Hendrickson, J. (1978). Error correction in foreign language teaching: Recent theory, research, and practice. The Modern Language Journal, 62(8), 387-398.

Hetzron, R. (1978). 'On the relative order of adjectives. In: Seiler, H. ed(s). Language Universals,165-184. Tübingen: Narr. 
Hinkel, E. (2018). Error Analysis. In J. I. Liontas, T. \& M. DelliCarpini (Eds.), The TESOL Encyclopedia of English Language Teaching (pp. 1-5). Hoboken: John Wiley \& Sons, Inc. Published. Doi:10.1002/9781118784235.eelt0058

Hunter, D. \& Smith, R. (2012). Unpackaging the past: “CLT” through ELJT keywords. ELT Journal, 66(4), 430-9.

Hussein, A. \& Mohammad, M. (2010). Negative L1 impact on L2 writing. International Journal of Humanities and Social Science, 18(1), 184-195.

James, C. (1998). Errors in language learning and use: Exploring error analysis, New York: Longman.

Kattan-Ibarra., J. \& Pountain, C. (2003). Modern Spanish grammar: A practical guide, London and New York: Routledge.

Kerr, P. (2014) Translation and own-language activities, Cambridge: Cambridge University Press.

Li, D. (1998). "It's always more difficult than you plan and imagine": Teachers' perceived difficulties in introducing the communicative approach in Southt Korea. TESOL Quarterly, 32(4), 677-703.

Lightbown, P.M \& Spada, N. (1990). Focus-on-form and corrective feedback in communicative language teaching: Effects on second language learning. Studies in Second Language Acquisition, 12(4), 429-448.

Macaro, E. (2005). Codeswitching in the L2 classroom: A communication and learning strategy. In E. Llurda (Ed.). Non-native language teachers. Perceptions, challenges and contributions to the profession, 63-84. New York: Springer.

McMahon, S. (2008). Multiple pre-nominal adjective usages by Asian L2 learners of English. Unpublished thesis. Liberty University, Virginia, the United States.

McNally, L., \& Kennedy, C. (2008). Adverbs and adjectives: Syntax, semantics, and discourse, Oxford: Oxford University Press.

North, B., \& Piccardo, E. (2016). Developing illustrative descriptors of aspects of mediation for the Common European Framework of Reference (CEFR). Language Teaching Surveys and Studies. 49(3), 455-459.

Pan, Y. (2010). The use of L1 in the foreign language classroom. Colombian Applied Linguistics Journal, 12(2), 87-96.

Parrott, M. (2010). Grammar for English language teachers (2 ${ }^{\text {nd }}$ ed.), Cambridge: Cambridge University Press. 
Phettongkam, H. (2013). Error Analysis and its'implications in communicative English language teaching. Thammasat Review, 16(3), 96-108.

Place, E., \& Torres-Rioseco, P. (1943). Contemporary Spanish grammar, New York: Oxford University Press.

Quirk, R., Greenbaum, S., Leech, G., \& Startvik, J. (1985). A comprehensive grammar of the English language, London: Longmans.

Ramsey, M. (1956). A textbook of modern Spanish, New York: Henry Holt and Company.

Sanchez Ruiz, R. \& Lopez Cirugeda, I. (2014.) Common errors made by Spanish graduate students to be avoided at B1 English oral exams. Encuentro, 23, 128-141.

Svenonius, P. (2007). 'The position of adjectives and other phrasal modifiers in the decomposition of the DP'. In: McNally, L., \& Kennedy, C. ed(s). Adverbs and adjectives: Syntax, semantics, and discourse, 16-42. Oxford: Oxford University Press.

Swan, M. (2005). Practical English usage ( $3^{\text {rd }}$ ed.), Oxford: Oxford University Press.

The British Council. (n.d). Retrieved from http://learnenglish.britishcouncil.org/ en/english-grammar/adjectives/order-adjectives

Tim, K.K. (2000). An investigation of subject-verb agreement errors in the interlanguage of ESL learners. Unpublished Maters Thesis, University of Malaya.

Velez-Rendon, G. (2003). English in Colombia: A sociolinguistic profile. World Englishes, 22(2), 185-198.

Whitley, S. (1986). Spanish/English contrasts: A course in Spanish linguistics, Washington, DC: Georgetown University Press.

Wulff, S. (2003). A multifactorial corpus analysis of adjective order in English. International Journal of Corpus Linguistics, 8 (2), 245-282. 


\section{Author}

* Andrew Connolly is an English teacher with over 8 years teaching experience. Currently, he is a teacher at Universidad EAN in Bogota, Colombia. Alongside this he is a certified IELTS (International English Language Testing System) examiner and holds a Master's degree in Applied Linguistics from the University of Leicester. His main interests within the field of English Language Teaching are CLIL (Content and Language Integrated Learning), error analysis, exam design, and teaching English for Academic purposes all with a focus, where possible, on the Colombian context.

ORCID: https://orcid.org/0000-0001-9916-3392 